concentration of cytochrome $c$ and by the abundance of its mitochondria and their enzymes ${ }^{5}$.

The little studied Harderian glands are known to contain, besides non-haem melanin(?) pigments, protoporphyrins which have been correlated with the susceptibility of rodents to carcinogenesis by light ${ }^{6,7}$ and to "spontaneous" tumours ${ }^{8}$. They give rise to "red tears", chromodacryorrhoea, after injection of acetylcholine ${ }^{9}$ and in poisoning with cholinergic substances, or on exposure to high temperature and high humidity ${ }^{10}$.

The high values of selenium-75 radioactivity found in the Harderian glands after a dose of labelled sodium selenite imply selenium plays some part in their function. Selenium dioxide can act as an oxidizing agent and is known to form sulphur trioxide from sulphur dioxide, becoming itself reduced to the elemental form ${ }^{11}$.

If selenite catalysed in vivo the formation of sulphate the distribution of the latter and possibly of sulphatases would be expected to be related. It is thus of interest that there is some parallelism between tho distribution in the organs of the rat of selenium-75 from sodium selenite labelled with selenium-75 and the activity of aryl sulphatases $^{12}$. A high sulphur-35 radioactivity has been detected by autoradiography in the brown fat after intraperitoneal injections of aryl sulphates ${ }^{13}$.

It has been suggested that selenium, a high concentration of which has been found in the rotina and iris of the human eye (and also of other species), may play a part in light perception ${ }^{14}$.

The high selenium-75 radioactivity present in the brown fat and in the Harderian glands of rats given sodium selenite labelled with selenium-75 indicates the need for further study of these rather specialized organs and of the interrelationship of their selenium and sulphur metabolism.

I thank Mr A. R. Henderson for valuable technical assistance.

Toxicology Research Unit,

R. Schoental

MRC Laboratories,

Woodmansterne Road,

Carshalton, Surrey.

Received January 25, 1968.

${ }^{1}$ Rosenfeld, I., and Beath, O. A., Selenium, Geobotany, Biochemistry, Toxicity and Nutrition (Academic Press, London, 1964).

${ }^{2}$ Schwarz, K., and Sweeney, E., Fed. Proc., 23, 421 (1964).

Cummins, L. M., and Martin, J. L., Biochemistry, 6, 3162 (1967).

- Schoental, R., Biochem. J., 108, 27 P (1967).

s Joel, C. D., in Handbook of Physiology, 5, 59 (1965).

- Figge, F. H. J., Cancer Res., 4, 465, 471, 482 (1944).

'Hueper, W. C., and Figge, F. H. J., Cancer Res., 5, 328 (1945).

${ }^{8}$ Figge, F. H. J., Strong, L. C., Strong, jun., L. C., and Shanbrom, A., Cancer Res., 2, 335 (1942).

- Tashiro, S., Smith, C. C., Badger, E., and Kezur, E., Proc. Soc. Exp. Biol. and Med., 44, 658 (1940).

${ }^{10}$ Collins, K. J., Quart. J. Exp. Physiol., 42, 24 (1957). ${ }^{1}$ Bagnall, K. W., Chemistry of Selenium, Tellurium and Polonium (Elsevier,

${ }^{12}$ Dodgson, K. S., Spencer, B., and Thomas, J., Biochem. J., 58, 452 (1953).

${ }_{13}$ PoweH, G. M., Curtis, C. G., and Dodgson, K. S., Biochem. Pharmacol., 16, 1997 (1967). 14 Taussky, H. H., Washington, A., Zubillaga, E., and Mithorat, A. T.,
Nature, 210, 949 (1966).

\section{Newberyite-its Formation in Human Urinary Calculi}

SEvERAL workers have reported the occurrence of newberyite, $\mathrm{MgHPO}_{4} \cdot 3 \mathrm{H}_{2} \mathrm{O}$, in the human urinary calculi, and we found it in 17 per cent of the stones studied in this laboratory ${ }^{1}$. Newberyite, however, is not mentioned by other workers who have also made extensive studies of the composition of calculi ${ }^{1}$. The stones in which we found newberyite were, apart from those in an allegedly modern Indonesian collection, all old, the Norwich ones dating from the eighteenth and nineteenth centuries. Data recently received on the Indonesian collection show that the stones were obtained from patients about twenty years ago and are therefore old enough for certain constituents to have undergone chemical change.

Struvite, $\mathrm{MgNH}_{4} \mathrm{PO}_{4} \cdot 6 \mathrm{H}_{2} \mathrm{O}$, which is a common constituent of urinary calculi, is known to decompose into newberyite ${ }^{1,2}$. Whitaker ${ }^{2}$ showed in experiments conducted at room temperature that the decomposition of synthetic single crystals of struvite into newberyite started after exposure to the atmosphere for 6 days and was complete in 6 months. Synthetic powder samples of struvite $(2-3 \mathrm{~g})$ were more stable, but complete decomposition to newberyite occurred within 10 months. On the other hand, we have found struvite both as a powder and as single erystals in many old calculi usually in the nucleus and interior regions. One good crystal from a stone developed a white powder of newberyite on the surface, but there had been no further decomposition after 12 months. The surface of the calculus removed from Napoleon III in 1873 (stone supplied by courtesy of the Royal College of Surgeons, London) consisted of struvite with only a trace of newberyite; the stone had, however, been kept in a tightly sealed container.

In viow of the instability of struvite, all calculi in which we found newberyite have been carofully examined. In most of them, it occurred as a fine white powder on the surface of the stone and X-ray photographs of material taken from there showed that struvite was frequently present. When newberyite had been found in the nucleus or interior regions, either the stone was very porous allowing ammonia and water to escape easily or, usually, only half a stone had been supplied (as in the Norwich collection) and the nucleus and interior sampled had been exposed for a considerable time. Again newberyite occurred as a fine white powder on the exposed surface and struvite was usually present. In several cases, stones with newberyite in central exposed regions were split open to provide a fresh surface. Samples taken from these surfaces had a reduced amount of newberyite or no trace of it, and an increase in the amount of struvite.

The question arises as to whether newberyite is ever deposited in stones as such or is always formed by the decomposition of struvite. The solubilities of struvite and newberyite in urine are influenced by the concentration and type of ions present, for example, the solubility of struvite in aqueous solutions is decreased by ammonia and increased by ammonium chloride. Although no experimental data are available to show that struvite is always more insoluble than newberyite other evidence indicates that newberyite was probably formed from struvite in every case.

I thank Dame Kathleen Lonsdale for her interest in this work and the Medical Research Council for financial support.

Department of Chemistry,

D. June Sutor

University College,

London.

Received February 2, 1968.

${ }^{1}$ Lonsdale, K., and Sutor, D. J., Science, 154, 1353 (1966).

${ }^{2}$ Whitaker, A., Min. Mag. (in the kress).

\section{MICROBIOLOGY}

\section{Photosuppression of Mitomycin-induced $\lambda$-Phage Development}

MiтомхсіN $C$, an effective anti-cancer agent, is also a potent inducer of $\lambda$-phage formation in lysogenic Escherichia coli $K 12$ ( $\lambda$ ) (refs. 1 and 2). In this report we show that mitomycin-induced phage formation and cell lysis can be suppressed when $E$. coli $K 12(\lambda)$ cells are exposed to light from a projection lamp. 